\title{
RESEARCH INTO BIOLOGICAL CHARACTERICTICS OF DRIED SAPROPEL
}

\author{
Rasma Tretjakova $^{1}$, Jūlija Grebeža ${ }^{2}$, Andris Martinovs ${ }^{1}$ \\ ${ }^{1}$ Rezeknes Augstskola, Faculty of Engineering, \\ Atbrivosanas aleja 115, Rezekne, LV-4601, Latvia. \\ ${ }^{2}$ Institute of Food Safety, Animal Health and Environment BIOR, \\ Liepu iela 33b, Rēzekne, LV-4600, Latvia.
}

\begin{abstract}
Microbiological characteristics of dried sapropel of Lake Rušona and Lake Ubagova and concrete containing sapropel and hemp sheaves (Ubagova Lake) have been studied. The antimicrobial activity was studied by the reference test cultures Staphylococcus aureus ATCC 25923, Salmonella enteritidis ATCC 13076, Enterococcus faecalis ATCC 29212, Bacillus cereus ATCC 10876, Escherichia coli ATCC 25922, Candida albicans ATCC 10231. Antibacterial activity on Staphylococcus aureus reference test cultures is stated in Rušona Lake sample before treatment with UV rays. Antibacterial activity is not stated in Ubagova Lake sapropel sample. 20 minutes' long UV ray treatment is not long enough to prevent the growth of sapropel materials. Both Rušona Lake and Ubagova Lake samples contain microorganisms that start growing and intensively reproducing in favourable conditions. When in contact with humidity, at the temperature from 18 to $37 \pm 1^{\circ} \mathrm{C}$, mold colonies form on concrete containing sapropel and hemp sheaves, for this reason this material should not get in contact with humidity when used in construction.
\end{abstract}

Keywords: bacteria, fungi, mold.

\section{INTRODUCTION}

Sapropel is the sediment of freshwater lake mud, which is made up of more than $95 \%$ organic substances and is formed on the bottom of the body of water as a result of incomplete decomposition (oxidation) of dying and sunken biomass (different aquatic plants, phytoplankton and zooplankton, living organisms, pollen and spores of highest plants) under conditions of oxygen deprivation. The sapropel is strategic natural resources, numerous studies have shown the possibility of the effective use of sapropels in bio-energy, food industry, chemical industry, agriculture, cattle-breeding, forestry, construction industry, medicine (balneology, pharmacology, mud therapy) and cosmetics [1] - [9]. There are noticeable resources of sapropel in Latvia but insufficient study prevents the use of it. Latvia has 2256 lakes with a total area of $1001 \mathrm{~km}^{2}$ or $1.5 \%$ of the country. The total area of mires is $6401 \mathrm{~km}^{2}$ or $9.9 \%$ of Latvia. Most lakes and bogs contain sapropel deposits. The State Geology Office of Latvia states that there are more than 750 million $\mathrm{m}^{3}$ of lake sapropel resources and about 1.5 billion $\mathrm{m} 3$ of sapropel reserves. There are about 2 billion $\mathrm{m}^{3}$ of joint sapropel resources in
Latvia [10]. Nowadays issues concerning ecological construction and production of environmentally friendly materials are getting even more important. A noticeable part of social resources has to be invested in construction materials, thus it is very important to produce effective and environmentally friendly materials by using local resources. Development of ecological construction materials and increasing application of them in construction expands because it gives an opportunity to save resources during production and does not pollute environment. These materials are fully recyclable and decompose in relatively short period of time after the exploitation. As the interest in economics that uses local natural resources increases, the study of sapropel use in construction material production is getting more topical. Several scientists [8], [10], [11], [12] point on use of sapropel in construction. Gružāns [13] economical calculations show that sapropel-concrete could become one of the cheapest and most available construction materials in the whole Latvia. But solid sapropel is a new, almost unused material yet. To find maximally effective application for sapropel, its mechanical, physical, chemical and biological 
characteristics should be known. The aim of this study is to determine the biological activity of solid sapropel materials.

\section{MATERIALS AND METHODS}

In experiments $\mathrm{Nr} 1$ to $\mathrm{Nr} 5$ two samples were tested - the 1st sample is sapropel from Diunoklis gulf of Lake Rušona, collected from upper layer (0.3 $0.5 \mathrm{~m}$ in depth), the 2nd sample is Lake Ubagova sapropel, collected from deeper layer. The samples were dried at the temperature of $20-23{ }^{0} \mathrm{C}$ and preserved in laboratory conditions for 3 months. Experiments were carried based on CLSI M100-S23 Performance standards for antimicrobial susceptibility testing [14]. In assessing of the antibacterial agents were used the following criteria: absence of zones around the wells for microbial growth inhibition or occurrence of zone areas.

For the evaluation of antimicrobial activity in experiments 1 to 4 were used the following test strains: Staphylococcus aureus ATCC 25923, Salmonella enteritidis ATCC 13076, Enterococcus faecalis ATCC 29212, Bacillus cereus ATCC 10876, Escherichia coli ATCC 25922, Candida albicans ATCC 10231. Reference test cultures were planted on PCA (Plate Count Agar) and incubated for $24 \mathrm{~h}$ in 37 $\pm 1{ }^{0} \mathrm{C}$ temperature.

In Experiment $\mathrm{Nr} 1$ sapropel samples are divided into small pieces. MHA (Mueller-Hinton agar) is melted in boiling water bath, then cooled to the temperature of $\sim 40{ }^{0} \mathrm{C}$, obtained broth is poured in sterile $90 \mathrm{~mm}$ Petri dishes. The mixture is allowed to solidify for 20 minutes. Reference cultures are inoculated in TSB (Tryptone Soya Broth), to 0.5 McFarland (the turbidity is evaluated by comparing to 0.5 McFarland standard). Sterile cotton swab is soaked in inoculant, pressed against the inner wall of test tube, then densely draw stripes on the surface of MHA, this action is repeated two times turning Petri dish for 60 degrees each time. The Petri dish is left to dry for 15 minutes. Then small sapropel material sample is put and pressed in the dish using sterile pincers.

In Experiment $\mathrm{Nr} 2$ after incubation reference cultures from PCA are inoculated in TSB, till 0.5 McFarland (the turbidity is evaluated by comparing to $0.5 \mathrm{McFarland}$ standard) and incubated in thermostat for $1 \mathrm{~h}$ at $37{ }^{\circ} \mathrm{C}$ temperature in order to get "refresh" substance. Sapropel samples are milled put into laminar and treated with UV rays. Sterile test tubes filled with MHA are melted in boiling water bath, then cooled to the temperature of $\sim 40{ }^{0} \mathrm{C}$, add reference cultures $1 \mathrm{ml}$ (incubated in TSB), mixed with electrical mixer (Vortex), obtained broth is poured in sterile $90 \mathrm{~mm}$ Petri dishes. The mixture is allowed to solidify for 20 minutes. Using sterile instrument a hole in the broth is made. Using sterile instrument the hole is filled with sapropel.
In Experiment $\mathrm{Nr} 3$ reference cultures are disseminated on PCA. Sapropel samples are milled put into laminar and treated with UV rays for 20 minutes. MHA is melted in boiling water bath, then cooled to the temperature of $\sim 40{ }^{\circ} \mathrm{C}$, obtained broth is poured in sterile $90 \mathrm{~mm}$ Petri dishes. Agar is allowed to solidify for 20 minutes. Reference cultures are inoculated in TSB, 0.5 McFarland (the turbidity is evaluated by comparing to $0.5 \mathrm{McF}$ arland standard). Sterile cotton swab is soaked in inoculated TSB, pressed against the inner wall of test tube, then densely draw stripes on the surface of MHA, this action is repeated two times turning Petri dish for 60 degrees each time. The Petri dish is left to dry for 15 minutes. Using sterile instrument a hole in the broth is made. Using sterile instrument $1 / 2$ of the hole is filled with sapropel.

In Experiment $\mathrm{Nr} 4$ broth and reference cultures are made as in experiment Nr. 3. Preparatory procedure of sapropel material is different - after treating with UV rays for 20 minutes, milled sapropel sample is poured out in sterile Petri dishes, saline is added, mixed, put in thermostat at $37{ }^{\circ} \mathrm{C}$ and is allowed to "maturate" for 30 minutes. Using sterile instrument a hole in the broth is made. Using sterile instrument the hole is filled with maturated in the thermostat sapropel.

In experiment $\mathrm{Nr} 5$ two microorganisms reference cultures have been used: Staphylococcus aureus ATCC 25923, Escherichia coli ATCC 25922. Reference cultures were planted on PCA and incubated for $24 \mathrm{~h}$ at $37^{0} \mathrm{C}$ temperature. Sapropel samples are milled, put into laminar and treated with $\mathrm{UV}$ rays for 20 minutes. Reference cultures are inoculated in TSB, 0.5 McFarland (the turbidity is evaluated by comparing to $0.5 \mathrm{McF}$ arland standard). 9 $\mathrm{ml}$ of inoculant with sterile pipette is taken into 3 test tubes. To the $1^{\text {st }}$ test tube $1 \mathrm{~g}$ of the $1^{\text {st }}$ sapropel sample is added, to the $2^{\text {nd }}$ test tube $1 \mathrm{~g}$ of the 2 nd sapropel sample is added, the $3^{\text {rd }}$ test tube - control. All test tubes substance is mixed. Test tubes are incubated in for $24 \mathrm{~h}$ at $37{ }^{\circ} \mathrm{C}$ temperature. Dilution from incubated TSB is made till $10^{-10}$ degree. $90 \mathrm{~mm}$ Petri dishes are filled with $1 \mathrm{ml}$ dilution from $10^{-6}$ till $10^{-10}$. It is melted on PCA, cooled to the temperature of $\sim 40^{\circ} \mathrm{C}$. Dilution is poured with PCA, mixed and agar is allowed to solidify for 20 minutes. It is incubated for $24 \mathrm{~h}$ at $37 \pm 1{ }^{0} \mathrm{C}$ temperature. Then colonies are counted.

In experiments $\mathrm{Nr} 6-9$ concrete containing sapropel and hemp sheaves have been tested.

Experiments are carried out based on standard LVS EN ISO 4833-1:2014 - enumeration of microorganisms.

In experiments $\mathrm{Nr} 6$ and $710 \pm 0.01 \mathrm{~g}$ of sample in a sterile bag is weighed out, then add 90 sodium chloride peptone solution. Substance is being mixed with electrical mixer Stomaher ${ }^{\mathrm{TM}}$ for 3 minutes, then 
allow the biggest parts to settle. From the obtained solution dilution from $10^{-3}$ - to $10^{-10}$ is made (with sterile pipette suspensions are taken into another test tube with $9 \mathrm{ml}$ sodium chloride peptone solution). 1 $\mathrm{ml}$ of tested sample dilution (from $10^{-2}-10^{-10}$ ) is taken on each of 2 sterile Petri dishes, then about $12-15 \mathrm{ml}$ PCA is poured on each dish, when cooled till $44-47$ ${ }^{0} \mathrm{C}$, is carefully mixed and allowed to solidify. Incubate for $72 \pm 4 \mathrm{~h}$ at $30 \pm 1{ }^{\circ} \mathrm{C}$ and $22 \pm 1{ }^{\circ} \mathrm{C}$. Calculate colonies (for calculating are chosen the dishes which contain less than 150 colonies).

Calculate the number $\mathrm{N}$ of mesophilic aerobic and facultative anaerobic microorganisms using the equation:

$$
N=\frac{\sum C}{V \cdot\left(n_{1}+0.1 \cdot n_{2}\right) \cdot d}
$$

where $C$ - sum of the colonies counted, V- the volume of inoculum applied on each dish $(1 \mathrm{ml}), \mathrm{n}_{1^{-}}$the number of dishes retained at the first dilution, $\mathrm{n}_{2}$ - the number of dishes retained at the second dilution, $\mathrm{d}$ the dilution factor -1 .

In experiment $\mathrm{Nr} 82 \pm 0.01 \mathrm{~g}$ of sample is weighed out on 4 sterile Petri dishes. $2 \mathrm{ml}$ of sterile water is poured on each dish, then mixed. Incubate at $22 \pm 1{ }^{0} \mathrm{C}, 30 \pm 1{ }^{0} \mathrm{C}, 37 \pm 1{ }^{0} \mathrm{C}$, at room temperature which fluctuates from $18{ }^{0} \mathrm{C}$ till $23{ }^{0} \mathrm{C}$. Every $24 \mathrm{~h}$ growth control is made, in order to avoid material desiccation, $1 \mathrm{ml}$ sterile water is added.

In experiment $\mathrm{Nr} 92 \pm 0.01 \mathrm{~g}$ of sample is weighed out on 4 sterile Petri dishes. $2 \mathrm{ml}$ of sterile water is poured on each dish, then mixed. Dishes are taken into "Whril-pack" sterile bags, closed hermetically. Incubate at $22^{0} \pm 1{ }^{0} \mathrm{C}, 30 \pm 1{ }^{0} \mathrm{C}, 37 \pm 1$ ${ }^{0} \mathrm{C}$, at room temperature. Growth control is made every $24 \mathrm{~h}$.

\section{RESULTS AND DISCUSSION}

In experiment $\mathrm{Nr} 1$ checking the antibacterial activity of sapropel materials on Staphylococcus aureus, Salmonella enteritidis, Enterococcus faecalis, Bacillus cereus, Escherichia coli , Candida albicans it has been noticed that Rušona Lake sapropel materials have Staphylococcus aureus $2 \mathrm{~mm}$ growth delay, in other reference cultures - Salmonella enteritidis, Enterococcus faecalis, Bacillus cereus, Escherichia coli, Candida albicans growth delay has not been stated. In its turn, the development of growth delay zone has not been noticed in any of Ubagova Lake sapropel material of applied reference cultures. Intense growth on broth of both studied materials has been noticed, colonies are large, with rugged edges, tarnished, white and cream-coloured.

In experiment $\mathrm{Nr} 2$, in order to evaluate growth delay and suppress the growth of sapropel natural microflora, sapropel was pulped and treated with UV rays; as a result, the development of delay zone has not been noticed neither in Rušona Lake sapropel materials, nor in Ubagova Lake sapropel materials with any of applied reference cultures. Findings are difficult to be read and interpreted, as sapropel has maturated and increased its volume $\sim 2$ times. Part of materials has been electrified and stuck to Petri dishes covers. Growth of both studied materials on broth has been noticed, colonies are large, with rugged edges, tarnished, white and cream-coloured.

In experiments $\mathrm{Nr} 3$ and 4, in order to prevent volume increasing, which disturbs to evaluate results effectively, moistened material has been used and the hole $1 / 2$ filled with studied material. As a result the development of delay zone has not been noticed neither in Rušona Lake sapropel materials, nor in Ubagova Lake sapropel materials with any of applied reference cultures. Findings are clearly to be read. Growth of both samples on broth has been noticed, colonies are large, with rugged edges, tarnished, white and cream-coloured.

In experiment 5, adding Rušona Lake sapropel material and Ubagova Lake sapropel material to Staphylococcus aureus and Escherichia coli suspensions, after $24 \mathrm{~h}$ period of incubation a number of microorganisms has not decreased, is observed the decreasing of the number of microorganisms comparing to control sample. Results of the study of antibacterial activity of test samples, presented in the Table 1.

TABLE 1.

ANTIBACTERIAL ACTIVITY OF TEST SAMPLES

\begin{tabular}{|c|c|c|c|}
\hline Reference test cultures & $\begin{array}{c}\text { Rušona Lake sapropel sample } \\
(\mathrm{kvv} / 1 \mathrm{ml})\end{array}$ & $\begin{array}{c}\text { Ubagova Lake sapropel } \\
\text { sample } \\
(\mathrm{kvv} / 1 \mathrm{ml})\end{array}$ & $\begin{array}{c}\text { Control } \\
(\mathrm{kvv} / 1 \mathrm{ml})\end{array}$ \\
\hline Staphylococcus aureus & $14 \times 10^{8}$ & $15 \times 10^{8}$ & $10 \times 10^{8}$ \\
\hline Escherichia coli & $16 \times 10^{8}$ & $14 \times 10^{8}$ & $12 \times 10^{8}$ \\
\hline
\end{tabular}

In experiment $\mathrm{Nr} 6$, studying concrete containing sapropel and hemp sheaves after $72 \mathrm{~h}$ of incubation at $30 \pm 1{ }^{\circ} \mathrm{C}$ temperature, the number of mesophilic aerobic and facultative anaerobic microorganisms is $7.5 \times 10^{6} \mathrm{kvv} / 1 \mathrm{~g}$ (Table 2).
In experiment $\mathrm{Nr} 7$, after $72 \mathrm{~h}$ of incubation at $22 \pm 1^{\circ} \mathrm{C}$ temperature, the number of mesophilic aerobic and facultative anaerobic microorganisms is $6.3 \times 10^{6} \mathrm{kvv} / 1 \mathrm{~g}$ (Table 2).

In experiment $\mathrm{Nr} 8$, incubating concrete containing sapropel and hemp sheaves without 
broth with added water, at all checked temperatures $\left(22 \pm 1{ }^{0} \mathrm{C}, 30 \pm 11^{0} \mathrm{C}, 37 \pm 1^{0} \mathrm{C}\right.$, room temperature, which fluctuates from $18{ }^{0} \mathrm{C}$ till 23 ${ }^{0} \mathrm{C}$ ), after 7 days is observed the increasing of mold colonies (Table 2).

In experiment $\mathrm{Nr}$ 9, incubating concrete containing sapropel and hemp sheaves without broth with added water in a sterile polyethylene bag, the increasing of mold colonies is observed at all checked temperatures $\left(22 \pm 1{ }^{0} \mathrm{C}, 30 \pm 1{ }^{0} \mathrm{C}, 37\right.$ $\pm 1{ }^{0} \mathrm{C}$ ), room temperature, which fluctuates from $18{ }^{\circ} \mathrm{C}$ till $23{ }^{0} \mathrm{C}$ after 5 days (Table 2).

TABLE 2.

BIOLOGICAL CHARACTERISTICS OF CONCRETE CONTAINING SAPROPEL AND HEMP SHEAVES

\begin{tabular}{|l|c|c|c|c|}
\hline \multicolumn{1}{|c|}{ Microorganisms } & $22 \pm 1{ }^{0} \mathrm{C}$ & $30 \pm 1{ }^{0} \mathrm{C}$ & $37 \pm 1{ }^{0} \mathrm{C}$ & $\begin{array}{c}\text { Room temperature } \\
18{ }^{0} \mathrm{C}-23^{0} \mathrm{C}\end{array}$ \\
\hline $\begin{array}{l}\text { Number of mesophilic aerobic } \\
\text { and facultative anaerobic } \\
\text { microorganisms }\end{array}$ & $6.3 \times 10^{6}$ & $7.5 \times 10^{6}$ & not checked & not checked \\
\hline $\begin{array}{l}\text { Mold colonies (Pates "Whril- } \\
\text { pack") }\end{array}$ & positive & positive & positive & positive \\
\hline Mold colonies (Plate) & positive & positive & positive & positive \\
\hline
\end{tabular}

Platonov at al. [2] states that sapropel protective antibiotic activity against E.coli, St.aureus, C.diphterie and fungi Candida was demonstrated. Strus at al. [15] studies have shown a slight antibacterial activity of sapropel against selected test cultures (Escherichia coli ATCC 25922, Pseudomonas aeruginosa ATCC 27853, Bacillus subtilis ATCC 6633, Proteus vulgaris ATCC 4636, Candida albicans ATCC 885/ 653). However, in this study, antibacterial activity of Rušona Lake sapropel sample has been observed only on Staphylococcus aureus, but Ubagova Lake sapropel sample has not shown anti-bacterial effect on any of applied microorganisms reference cultures. Stankeviča, Kḷaviņš [10] point out that anti-bacterial effect is characteristic of fresh sapropel. Also Marčenko and Gurinovich [16] mention that microorganisms that educe antibiotics, which are antagonistic chain of pathogenic saprophilic microorganisms have been found in fresh sapropel. In this study dried sapropel has been studied.

The research shows that sapropels contain an extremely large amount of microorganisms - in $1 \mathrm{~g}$ of fresh sapropels there are 12 billion microorganisms in its top layer. In the lower layers, starting from around $0.6-1.0 \mathrm{~m}$ from the lake bed surface the amount of microorganisms decreases [17]. In Latvia, in 1965 Stūris [18] in his research of Kaniera Lake and Babītes Lake stated that microorganisms distribution and biochemical activity directly depend on the depth of sapropel layer and season.

In this study sapropel samples have been taken from different lakes and depths, as a result its biological activity is different.

Also Stankeviča and Kḷviņš [10] point out that content and characteristics of sapropels from various deposits are very different and depend on the productivity of the water body, characteristics of the aboveground water flow, and climatic conditions. Before using concrete containing sapropel in construction, its biological characteristics and chemical content must be studied. Specific features of biological activity correlate with chemical content of substances [2]. Antibiotics and sulphanilamide in sapropels are synthesized by fungus and actinobacteria.

Possibly, chemical characteristics of fresh and dried sapropel are different, natural microflora changes and it does not show typical antibacterial characteristics. In order to approve this hypothesis, chemical characteristics of fresh and dried sapropel at different depths from several lakes must be studied.

While incubating Rušona and Ubagova Lakes sapropel samples on broth the growth has been noticed, which points out that not only fresh sapropel, but also dried samples have microorganisms that are able to grow. This characteristic has been observed after treatment with UV rays, so 20 minutes' treatment with UV rays do not eliminate all natural microflora of samples.

Studying concrete containing sapropel and hemp sheaves construction materials it has been stated that they contain a big number of microorganisms. When in contact with humidity, at the temperature from 18 ${ }^{0} \mathrm{C}$ to $37{ }^{0} \mathrm{C}$, mold has developed on sapropel and hemp sheaves construction materials. The mold is a significant risk factor for health, especially in relation to the diseases affecting the human respiratory and immune system. Overall four types of health problems are observed in relation to moisture and mold exposure - allergic diseases, respiratory irritation, infections and toxicological effects [19].

\section{CONCLUSION}

1. Both Rušona Lake and Ubagova Lake dried sapropel samples contain microorganisms, which begin to grow and reproduce intensively in enabling circumstances. 
2. 20 minutes' treatment with UV rays is not enough to eliminate the growth of sapropel made samples.

3. Rušona Lake sapropel test sample has antimicrobial activity on Staphylococcus aureus reference culture before it is treated with UV rays.

4. Ubagova Lake sapropel test sample does not have antimicrobial activity.

5. When in contact with humidity, at the temperature from $22 \pm 1{ }^{0} \mathrm{C}, 30 \pm 1{ }^{0} \mathrm{C}, \quad 37 \pm 1$ ${ }^{0} \mathrm{C}$, room temperature $\left(18{ }^{0} \mathrm{C}\right.$ till $\left.23{ }^{0} \mathrm{C}\right)$, mold colonies form on concrete containing sapropel and hemp sheaves, for this reason this material should not get in contact with humidity when used in construction.

\section{REFERENCES}

[1] Nikolaeva L. A., Latyshev V. G. and Burenina O. N. Fuel Briquettes from Brown Coals of Yakutia. ISSN 0361-5219, Solid Fuel Chemistry, vol. 43, No. 2, pp. 109-112, 2009.

[2] Platonov V.V., Khadartsev A.A., Chunosov S.N. and Fridzon K.Y. The biological effect of sapropel. Fundamental research, vol. 9 (11), $2474-2480,2014 . \quad$ [Платонов В.В., Хадарцев А.А., Чуносов С.Н., Фридзон К.Я Биологическое действие сапропеля. Фундаментальные исследования, 9 (11), 2474 - 2480, 2014].

[3] Kireicheva L.V. and Khokhlova O.B. Sapropels: composition, properties, applications. Moscow, pp. 124, 1998. [Кирейчева Л.В., Хохлова О.Б. Сапропели: состав, свойства, применение. М. 124 с., 1998].

[4] Ostrovskij M. V. Testing HUMIN PLUS Microfertilizer. European Agrophysical Journal, vol. 1(2), pp. $77-83,2014$.

[5] Tsukanov S. V., Owayski F., Zeidan I., Zeidan A., Uptis I., Apse J. and Ostrovskij M. V. Application of Organic Fertilizers Based on Sapropel and Peat in Countries of Middle East. European Agrophysical Journal, vol. 1(3), pp.118 - 128, 2014.

[6] Kitapova R.R. and Ziganshin A.U. Biologic Activity of Humic Substances from Peat and Sapropel. Kazanskiy meditsinskiy zhurnal, vol. 1, pp. 84-89, 2015.

[7] Schepetkin I., Khlebnikov A., Kwon B.S. Medical drugs from humus matter: Focus on mumie. Drug Development Research, vol. 57(3), pp. 140 - 159, 2002.

[8] Pleiksnis S. and Teirumnieka E. „Concrete containing sapropel and hemp sheaves for insulation of buildings," L. R. Patent 14869, C04B18/18, C04B18/24, June 20, 2014.
[9] Obuka V., Korjakins A., Brencis R., Preikšs I., Purmalis O., Stankeviča K., Kḷaviņš M. Sapropel/Peat-Wood Chip Insulation Materials and Their Properties. Materials Sciences and Applied Chemistry, vol. 29, pp.127-136, 2013.

[10] Stankeviča K. and Kḷaviņš M. Sapropel and its application possibilities. Materials Sciences and Applied Chemistry, vol. 29, pp.109-126, 2013. Available from: file:///C:/Users/user/Desktop/pub18075.pdf

[11] Vimba B. "Thermal dissolution of sapropel and chemical characteristics of obtained material”, Vimba B. „Sapropeļa termiskā šķīināāšana un iegūto produktu ķ̄̄miskais raksturojums". Disertācija, Latvijas Lauksaimniecības Akadēmija, Rìga, 1956.

[12] Kurzo B.V. Regularity of development and problems in using sapropel. Minsk, [Курзо Б. В. Закономерности формирования и проблемы использования сапропеля. Минск, 224 с. 2005].

[13] Gružāns A. Sapropeḷbetons. LLA raksti, Nr.9, 547 - 561. lpp., 1960 , in Stankeviča K. and Kḷavinšs M. Sapropel and its application possibilities. Materials Sciences and Applied Chemistry, vol.29, pp.109-126, 2013.

[14] Performance standards for antimicrobial susceptibility testing. 23rd informational supplement. CLSI M100-S23. Clinical Microbiologie Procedures Handbook. American Society for Microbyologie, Washington, USA. 2004.

[15] Strus O.E., Polovko N.P., Maloshtan L.M. and Solodchenko T.P. The study of the properties of sapropel deposits of Pribich. Problems of ecological and medical genetics and clinical immunology, vol. 3 (123), 2014.

[16] Marchenko L.O., Gurinovich E.S. Microbiological research into sapropel of Belorussian lakes. Problems in using sapropel in national economy. Minsk, Science and Engineering, [Марченко Л.О., Гуринович Е. С. Микробиологические исследования сапропелей Белорусских озер. Проблемы использования сапропелей в народном хозяйстве. Минск, Наука и техника, с. 74-81., 1976].

[17] Kuznecov S. I. The microflora of lakes and its geochemical activity. 440 pp., 1970. [Кузнецов С. И. Микрофлора озёр и её геохимическая деятельность. Л., изд. Наука, 440 с., 1970].

[18] Sturis T. Researches into sapropel microflora of Kaniera and Babītes Lakes. Dissertation summary. Riga, Institute of experimental and clinical medicine of Latvia, Sturis, T. Kañiera un Babītes ezera sapropeļa dūnnu mikrofloras pétījumi. Disertācijas kopsavilkums. Rīga, Latvijas eksperimentālas un klīniskas medicīnas institūts, 1965.

[19] Sahakian N.M., Park J.H., Cox-Ganse J.M. Dampness and Mold in the Indoor Environment: Implications for Asthma. Immunology and Allergy Clinics of North America, vol. 28 (3), pp. 485-505, 2008 